\title{
Suriyeli Göçmenlerin Yabancı Dil Olarak Türkçe Öğrenirken Karşılaştıkları Sorunlar ve Çözüm Önerileri
}

\author{
Kerim Ünal \\ Mersin Üniversitesi, Eğitim Fakültesi, Yabancı Diller Eğitimi Bölümü \\ kerimunal@mersin.edu.tr \\ ORCID ID: https://orcid.org/ 0000-0003-2005-851X \\ Serdarhan Musa Taşkaya \\ Mersin Üniversitesi, Eğitim Fakültesi, Temel Eğitim Anabilim Dalı \\ serdarhan@gmail.com \\ ORCID ID: https://orcid.org/0000-0003-0618-0084 \\ Gökhan Ersoy \\ Mersin Üniversitesi, Eğitim Fakültesi, Temel Eğitim Anabilim Dalı \\ gkhn.307667@gmail.com \\ ORCID ID: https://orcid.org/0000-0002-2192-4523
}

Araştırma Makalesi

\begin{tabular}{llllll}
\hline Geliş Tarihi: & 20.10 .2018 & Revize Tarihi: & 18.12.2018 & Kabul Tarihi: & 25.12.2018
\end{tabular}

\section{Attf Bilgisi}

Ünal, K., Taşkaya, S. M. ve Ersoy, G. (2018). Suriyeli göçmenlerin yabanc1 dil olarak Türkçe öğrenirken karşılaştıkları sorunlar ve çözüm önerileri, Ahi Evran Üniversitesi Sosyal Bilimler Enstitüsü Dergisi, 4(2), 134149.

ÖZ

2011 y1lında Suriye'de başlayan iç savaş ülkemizi maddi ve manevi olarak etkilemiştir. Suriye'den milyonlarca göçmen ülkemize göç etmiştir. Göç olayları neticesinde farklı kültürlere sahip insanların bir arada yaşama zorunluluğu bazı sorunları ortaya çıkarmıştır. Ortaya çıkan en önemli sorunlardan biri olan eğitim, büyük bir planlama istemektedir. Eğitimde ise öncelikli sorun Suriyelilerin ana dilinin Türkçe olmamasıdır. Bu nedenle Türkçe öğretimi öncelik kazanmıştır. Türkçe öğretimi için Milli Eğitim Bakanlığı, üniversiteler ve sivil toplum örgütleri çeşitli kurslar açmıştır. Üniversitelerde Türkçe öğretimi, Türkçe Öğretim Merkezi aracılığıyla yürütülmektedir. Çalışmada, göçmenlerin Türkçe öğrenirken karşılaştıkları sorunları, sorunlara üretilen çözümleri, Türkçeyi hangi durumlarda ve ne sıklıkla kullandıklarını ortaya koymak amaçlanmıştır. Bu nitel çalışmada, yarı yapılandırılmış görüşme formu kullanılmış ve 2016-2017 öğretim yılında Mersin Üniversitesinde B-2 seviyesinde Türkçe eğitimi alan 33 Suriyeli göçmen ile yürütülmüştür. Verileri analiz etmek için içerik analiz yöntemi kullanılmıştır. Analiz sonucunda Türkçe cümle yapısının farklı olması, öğrencilere geri bildirimde bulunulmaması, özgüven eksikliği gibi çeşitli sorunlarla karşılaşan Suriyeli göçmenlerin Türkçeyi en çok günlük ihtiyaçlarında kullandıkları ortaya çıkmıştır.

Anahtar Kelimeler: Yabancilara Türkçe öğretimi, göçmen, sorun.

\section{The Problems That The Syrian Emigrants Face While Learning Turkish as a Foreign Language and Their Solution Suggestions}

\begin{abstract}
The civil war that started in 2011 has influenced our country materially and morally. Millions of emigrants have migrated into our country from Syria. As a result of this migration, the necessity for people from different cultures to live together has aroused some problems. Education, one of the most important problems, requires a major planning. The main problem of education is the fact that Syrian people's mother-tongue is not Turkish. Therefore, teaching Turkish takes primacy. The ministry of education, universities and some non-governmental organizations have opened Turkish courses for Syrian people. Teaching Turkish at universities has been carried out by Teaching Turkish Centers. This study aims to find out the problems that these emigrants have faced while learning Turkish, the solutions that have been suggested for these problems, and how often and in which conditions they use Turkish. This qualitative research has been conducted with 33 Syrian emigrants who took a B-2 level Turkish course at Mersin University in 2016-2017 academic year, through semi-structured interview form. To analyze the data, content analysis method was used. The analysis reveals that the Syrian emigrants facing such problems as different Turkish sentence structure, lack of feedback and lack of self-confidence in their Turkish courses use Turkish in their daily life for daily-needs.

Key words: Teaching Turkish to foreigners, imigrants, problems
\end{abstract}




\section{Giriş}

"İnsanoğlu, varoluşundan bugüne kadar istemli ya da istemsiz bir şekilde coğrafyalar arasında sürekli hareket veya göç halindedir. Bu göçlerin en önemli nedenlerinden birisi de kargaşadır" (Akkaya, 2013, s.180). Kargaşanın en önemli sebebi ise bir ülkenin doğru ya da yanlış, kasıtlı ya da kasıtsız kaderini belirleme isteği olan iç savaştır. İç savaşlar neticesinde birçok sorun ortaya çıkmaktadır. Kişisel sorunların yanı sıra özellikle kitlesel sorunlar sadece o ülke ve vatandaşlarını değil yakın coğrafyadaki tüm ülkeleri ve vatandaşlarını çeşitli yönlerden etkilemektedir. Bu kitlesel sorunlardan bazıları beslenme, barınma, salgın hastalıklar ve güvenlik sorunlarıdır. Ancak, kitlesel sorunların en başında savaşlar gelmektedir ve bu savaşlar ülke insanını göçe zorlamaktadır (Tunç, 2015). Ekonomik, toplumsal ve siyasal nedenler neticesinde göçler meydana gelmekte ve insanlar göçmen sıfatıyla başka ülkelere sığınmaktadır. İçinde bulunduğumuz yüzyılda ve yakın coğrafyamızda yaşanan iç savaşlar ve siyasi değişimler sonucunda kitlesel göçler tetiklenmiş ve insanlar başka ülkelere göçmen olarak sığınmak zorunda kalmıştır (Lordoğlu, 2015). Fakat göç olgusunu sadece yer değiştirme eylemi ile sınırlandırmamak gerekir. Aynı zamanda göç, var olan yaşam kalitesini arttırmak umuduyla bulundukları yeri bırakıp başka bölgelere giderek kalıcı veya geçici yerleşmeler olarak da tanımlanabilir.

"Göç; kısaca, ekonomik, toplumsal veya siyasal nedenlerle insanların bireysel ya da kitlesel olarak yer değiştirme eylemi olarak tanımlanmaktadır" (Şahin, 2001, s. 59). Türkiye'nin coğrafi konumuna bakıldığında komşu ülkelerdeki kargaşa ve iç savaşın etkileri, batıya yüzünü dönmüş olan Türkiye'nin peşini bırakmaz. 17 Aralık 2010'da Tunus'ta başlayan ve “Arap Baharı" olarak adlandırılan dönüşüm süreci, Ocak 2011'de Suriye'ye de sıçramıştır. Suriye'de Mart 2011'den bu yana devam eden çatışma ve kargaşa ortamında on binlerce kişi hayatını kaybetmiş, yaralanmış ve milyonlarca kişi ise ülkelerini terk etmek zorunda kalmıştır. Türkiye Doğu Akdeniz havzasında, uluslararası göç rejimleri içinde Avrupa'nın ana giriş kapısı; Asya, Afrika ve Orta Doğu göçmenlerinin çıkış yeri olması açılarından öncelikli bir yeri bulunmaktadır.

2011 yılında Suriye'de başlayan iç savaşın etkileri ülkemizi de maddi ve manevi olarak etkilemiştir. Savaştan kaçan büyük bir göçmen grubu ülkemize gelmiştir. İstenmeyen bu süreçte, Türkiye hem bir göç geçiş ülkesi hem de sınırdaş olarak Suriye'de yaşanan iç savaşı en yakından hisseden birkaç ülkeden biridir. Türkiye, Suriyeli göçmenler için zorunlu ev sahibi olarak önemli fedakârlıklarda bulunmaktadır. Sayıları milyonlarla ifade edilen Suriyeliler, başta Suriye'ye komşu iller ve büyükşsehirler olmak üzere birçok ile dağılmıştır. Bunun sonucunda ülkemizin birçok yerinde başka kültürlere ait insanlar bir araya gelmiştir. İnsanların bir arada yaşama zorunluluğu birçok sorunu da beraberinde getirmiştir (Aksoy, 2012). Uluslararası göç olgusunun ortaya çıkardığı en önemli sorunların başında farklı kültürlerden gelen insanların bir arada yaşamaları, farklılıklarla baş etmeleri ve iletişim engellerini aşmaları gelmektedir. Bu sorunlar şu alanlarda görülmektedir: Ekonomik, psikolojik, sosyal, sağlik, eğitim...

İlk temel sorunları fiziksel ihtiyaçlarını karşılamak olan bu insanların, daha sonraki en temel sorunu ise bulundukları toplumun dilini, değer ve normlarını öğrenip uyum sağlamaktır. Bizler genel olarak tüm bu dil, değer ve normlara kültür diyebiliriz. "Kültür, bir toplumun geçmiş yaşamından beri biriktirdiği bütün değerlerdir. Kültürü oluşturan insanlardır; onların yaşayışı, giyim kuşamı, inançları, konuştuğu dili, kısacası yaptığı her şeydir... Kültürü oluşturan en önemli öge ise dildir" (Okur, 2013,s. 15). İnsanlar topluluk biçiminde yaşamaya başladığı andan itibaren ortak bir uzlaşma aracına ihtiyaç duymuş, bunun için birçok iletişim aracı bulmuştur. Bu araçlar içerisinde dil, insanlar arasında uzlaşmayı sağlayan en etkili ve önemli araç olmuştur. "Dil, insanlar arasında duygu ve düşüncelerini anlatmaya yarayan, bireyin sosyal ve bilişsel gelişiminde etkili olan; aynı zamanda zihinsel gelişimin göstergesi ve anlamanın aracıdır" (Özbay ve Melanlığlu, 2008, s. 31). Tanımlardan da anlaşılacağı üzere kültürel değerler konuşulan dil üzerinde, dil ise kültür üzerinde etkilidir. Bu iki olgu iç içe geçmiş halkalar gibidir. Birbirlerinden ayrılmaları, dağılmaları demektir. Bir toplumda yaşayan 
bireyler ise o toplumda konuşulan ortak dili ve yanı sıra toplumsal kültürü öğrenerek büyürler. Yabancı dil öğrenmek sadece o dilin cümle yapısını öğrenmek değil, aynı zamanda büyüdüğü kültürün dışında başka kültürleri tanıma firsatı bulmak, bu iki kültürü karşılaştırmak ve bu doğrultuda kendini geliştirmek demektir.

"Bir toplumda konuşulan dili tüm bireyler önce aile içinde etkileşerek daha sonra da toplum hayatına ilk girdiği günden itibaren çevrelerindeki arkadaşları, komşuları, akrabaları, öğretmenleri, medya iletişim araçları vasıtasıyla öğrenir ve geliştirirler" (Yaylı ve Bayyurt, 2014, s. 29). Böyle bir süreç ülkemizde bulunan yabancılar için daha önceden var olmadığından üzerlerinde psikolojik bir bask1 yaratarak dil öğrenmeyi zorunlu kılmaktadır. Bu açıdan bakıldığında ortaya çıkan en önemli sorunlardan biri de eğitimdir. Eğitim, Türkiye'deki göçmenlerin adaptasyonundaki en temel yardımcımızdır. Çünkü diğer sorunların çözümünü de içinde barındırır. Bu yüzden eğitim, büyük bir özen ve emek istemektedir. Eğitimde ise öncelikli sorun Suriyelilerin ana dilinin Türkçe olmamasıdır. Bu nedenle Türkçe öğretimi öncelik kazanmıştır. Türkçe öğretimi için bakanlık, üniversiteler ve sivil toplum örgütleri çeşitli kurslar açmıştır. Üniversitelerde ise Türkçe öğretimi, Türkçe Öğretim Merkezi (TÖMER) aracılığıyla yürütülmektedir. Türkçe Öğretim Merkezlerinde, Yunus Emre Enstitüsüne bağlı eğitim kurumlarında ve diğer kurslarda Türkçe öğretimi konusunda çeşitli sorunlar yaşandığı birçok araştırmacı tarafindan ifade edilmiştir. Türkçe öğretiminin hangi kitleye yapılacağı bu noktada önemlidir. Normal şartlar altında, hiçbir baskının ve zorunluluğun etkisi altında kalmaksızın kendi kişisel tercihi sonucunda Türkçeyi yabancı dil olarak öğrenmek isteyen yabancılarla, kendi tercihi dışında hayatını idame ettirmek ve başka bir topluma adapte olmak zorunda olan göçmenlerin Türkçeyi öğrenme konusunda elbette farklı sorunları olacaktır. Bu sorunlar hazırbulunuşluk, öğrenme isteği, iki grup arasındaki sosyoekonomik, kültürel ve psikolojik farklılıklardır. Birçok olumsuz etmeni bünyesinde barındıran ikinci kitleye Türkçe öğretimi çoğu zaman daha zordur. $\mathrm{Bu}$ süreci kolaylaştırmak adına öncelikle eğitim alacak kitleyi tam olarak incelemek ve bu süreçte nelere dikkat edilmesi gerektiğini doğru saptamak gerekir. "Bu noktada mültecilere dil öğretimi yapılırken, dilin hangi düzeyde öğretileceği, nelerin öğretileceği, hangi dilsel becerilerin geliştirilmesine ağırlık verileceği gibi konular gündeme gelmektedir. Bu bağlamda Suriyeli göçmenlerin dil ihtiyaçlarının saptanması, onlar için düzenlenecek kursların içeriklerinin belirlenmesi ve ihtiyaca göre eğitim ortamının düzenlenmesi bakımından önem taşımaktadır" (Bölükbaş, 2016, s. 21).

Yabancılar için hazırlanan Türkçe öğretimi programlarının öğrencilerin ana diline, yaşına, eğitim düzeyine ve kültürüne göre hazırlanmayışı Türkçe öğretiminin sorunlarından biridir. $\mathrm{Bu}$ bağlamda öğrenenin dâhil olduğu kitlesel özelliklerinin yanında kişisel özellikleri dikkate alınmalıdır. Programla birlikte Türkçe öğretiminde kullanılan yöntem ve materyallerin çağın koşullarına uygun olmayışı ve eksikliklerinin bulunması da önemli sorunların kaynağı durumundadır. Tüm bu tespitler dikkate alınarak Türkçe öğretim programlarının geliştirilmesi gerekmektedir. Yabancılara Türkçe öğretim programı hazırlanırken her alanda uzman kişilerle çalışılmalı ve bu öğretim uzmanları, hazırladıkları programın yeterliliğini ve uygunluğunu belirleyebilmek için diğer disiplin uzmanlarıyla işbirliği içinde olmalıdırlar (Ünlü, 2011). Program hazırlama aşamasında, alan uzmanları arasında işbirliği programın işlevselliği açısından önem taşımaktadır. Türkçe öğretimini zorlayan bazı nedenler ise öğrenilen dilin ve mevcut anadilin söylemsel farklılıklarından kaynaklanmaktadır. Derman'a (2010) göre, Türkiye Türkçesini konuşurken yabancı uyruklu öğrenciler dilin seslendirilmesi noktasında kendilerini eksik görmektedirler.

Bölükbaş’a (2011) göre, Arap öğrencilerin sözcük seçimi konusundaki yanlışlarının \%60,3’ü anadillerinden yaptıkları olumsuz aktarımlardan kaynaklanmaktadır. Bu yapılan olumsuz aktarımların ortadan kalkması için programın dışında öğrenenin sosyal hayatta daha fazla bulunmaları ve yaşantıya bağlı düzeltmeleri kendileri yapıp öğrenmeyi içselleştirip kalıcı hale getirmelidirler. "Bir yabancı dili ve o dille konuşan insanları duyma veya seslerini ayırt edebilme, dilin yapısal özelliklerine dair tahminlerde ve çıkarımlarda bulunma, hedef kitlenin gayreti ve o dili konuşan insanlarla ne kadar vakit geçirdiğine bağlı olarak değişiklik göstermektedir" (Demirci 2015, s. 339). Bunun yanında "dil öğretiminde öğrencinin dili öğrenme isteğinin nedeni, nerede kullanacağının ve ne şekilde kullanacağının belirlenmesi olan ihtiyaç analizi, öğrencinin ihtiyacının öncelikle hangi beceri olduğu, 
dili öğrenmek için ne kadar süre ayırdığı gibi konuların planlanmasına yardımcı olur" (Barın, 2008, s.139).

Sonuç olarak Türkçe öğrenirken birçok sorunla karşılaşan ve bu sebeple toplumsal adaptasyonu geciken Suriyeli göçmenlerin "dil öğrenme ihtiyaçlarının tespit edilmesi ve öğretimin bu ihtiyaçlardan hareketle hazırlanacak olan programlara uygun olarak yürütülmesi Suriyeli misafirlerin Türkiye'deki hayata uyum sağlaması ve kültürlenmesi açısından önem taşımaktadır" (Büyükikiz ve Çangal, 2016, s.1417). Suriyeli göçmenlerin Türkçe öğrenirken karşılaştıkları sorunları belirlemek amacıyla yapılan bu çalışmadan elde edilen verilerin, konuyla ilgili bundan sonraki süreçlerde Türkçe öğretim programları düzenlenirken yardımcı olacağı düşünülmektedir. Ayrıca eğitim, sosyokültürel ve ekonomik alanlarda ilgili kamu kuruluşlarının gereken politikaları oluşturabilmeleri açısından da önem arz etmektedir.

\section{Yöntem}

Araştırmada nitel yöntemlerden birisi olan özel durum yöntemi kullanılmıştır. "Özel durum yöntemi, güncel bir durum veya gruplar üzerine odaklaşarak derinlemesine inceleme yapmak olarak tanımlanmaktadır" (Ekiz, 2009, s.45). Suriyeli göçmenlerin yabancı dil olarak Türkçe öğrenme süreçlerinde yaşadıkları sorunları ve Suriyeli göçmenlerin bu sorunlar için ürettikleri çözüm önerilerini belirlemek için dört sorudan oluşan açık uçlu görüşme formu oluşturulmuş ve çalşmaya gönüllü olarak katılmak isteyen Suriyeli göçmenlerin, bu formu gerek Türkçe gerekse İngilizce olarak doldurmaları istenmiştir. Araştırma sonunda ulaşılan verilerin çözümlenmesinde "belirli kurallara dayalı kodlamalarla bir metnin bazı sözcüklerinin daha küçük içerik kategorileri ile özetlendiği sistematik, yinelenebilir bir tekniktir" (Büyüköztürk, Çakmak, Akgün, Karadeniz ve Demirel, 2017, s.259) olan içerik analizi tekniği kullanılmıştır.

\section{Çalışma Grubu}

Bu çalışma, 2016-2017 öğretim yılında Mersin Üniversitesi Türkçe öğretim merkezinde B-2 seviyesinde yabancı dil olarak Türkçe eğitimi alan ve çalışmaya gönüllü olarak katılan 13'ü kadın, 20'si erkek toplam 33 Suriyeli göçmen ile yürütülmüştür. Çalışmaya katılan Suriyeli göçmenlerin sekizi (5E; 3K), ikinci kez yabancı dil olarak Türkçe eğitimi aldıklarını, diğerleri ise ilk kez yabancı dil olarak Türkçe eğitimi aldıklarını vurgulamışlardır. Ayrıca çalışmaya katılan Suriyeli göçmenlerin 10'u dört yıldır, 12'si üç yıldır ve 11'i iki yıldır Türkiye'de olduklarını ve hem evde hem de zorunlu olmadıkça toplum içinde kendi ana dilerini konuştuklarını ifade etmişlerdir.

\section{Verilerin Toplanması ve Analizi}

Verilerin toplanması sürecinde, iki araştırmacı tarafından geliştirilen dört açık uçlu sorudan oluşan görüşme formu kullanılmıştır. Görüşme formunda kullanılan sorular üç dil uzmanı ve bir ölçme değerlendirme uzmanına gösterilmiş ve soruların istenilen amaca uygun olduğu belirlenmiştir. Araştırmanın verileri, yabancı dil olarak Türkçe dersine giren öğretim görevlileri tarafından bir ders saati sürecinde toplanmıştır. Araştırma verilerinin analizinde, içerik analizi tekniği kullanılmıştır. Analiz sürecinde üç araştırmacı, Suriyeli göçmenlerin sorulara vermiş oldukları cevapları ayrı ayrı incelemişler; tema ve alt temaları belirlemişlerdir. Araştırmacıların elde ettiği tema ve alt temalar karşılaştırılmış ve Miles ve Huberman'ın (1994) Güvenirlik formülü (Güvenirlik = Görüş birliği / (Görüş birliğgi + Görüş ayrılığı) kullanılarak güvenirlik hesaplanmıştır. Araştırmacıların, tema ve alt temalarda görüş birliğine ulaşma oranları \% 95 olarak bulunmuştur.

\section{Bulgular}

Suriyeli göçmenlerin "yabancı dil olarak Türkçe öğrenirken ne tür sorunlarla karş1laştınız" sorusuna verdikleri cevaplar incelendiğinde, Suriyeli göçmenlerin yabancı dil olarak Türkçe öğrenirken karşılaştıkları sorunların dil becerileri, eğitim süreci ve bireysel özellikler başlıkları altında toplandığ1 görülmüştür. Elde edilen sonuçlar Tablo 1'de verilmiştir. 
Tablo 1

Suriyeli Göçmenlerin Yabancı Dil Olarak Türkçe Öğrenirken Karşılaştıkları Sorunlar

\begin{tabular}{lll} 
Dil Becerileri & Eğitim Süreci & Bireysel Özellikler \\
Okuma & Öğretmen & Anadili kullanma \\
Dinleme & İçerik & Özgüven \\
Yazma & Ders süresi & Kişisel özellik \\
Konuşma & Kaynaklar & Diğer \\
Telaffuz & & \\
Dil bilgisi & & \\
Kelime & & \\
\hline
\end{tabular}

Tablo 1 incelendiğinde, Suriyeli göçmenlerin yabancı dil olarak Türkçe öğrenme süreçlerinde dil becerilerine yönelik sorunların; okuma, dinleme, yazma, konuşma, telaffuz, kelime ve dil bilgisi kaynaklı sorunlar olduğu görülmüştür. Suriyeli göçmenler öğretmen, dersin içeriği ve süresi ve dil öğrenme süreçlerinde kullandıkları ders materyalleri gibi eğitim sürecinden kaynaklı sorunlar yaşadıklarının altını çizmişlerdir. Ayrıca Suriyeli göçmenler, yabancı dil olarak Türkçe öğrenme süreçlerinde, kendi ana dillerini kullanma eğilimi, öz güven eksikliği ve diğer kişisel özelliklerinden kaynaklı sorunlar da yaşadıklarını vurgulamışlardır.

Suriyeli göçmenlerin yabancı dil olarak Türkçe öğrenme süreçlerinde dil becerilerine yönelik karşılaştıkları sorunlar ve bu sorunlara getirdikleri çözüm önerilerinden elde edilen sonuçlar Tablo 2 'de verilmiştir.

Tablo 2

Suriyeli Göçmenlerin Türkçe Öğrenme Süreçlerinde Dil Becerilerine Yönelik Karşılaştıkları Sorunlar ve Çözüm Önerileri

\begin{tabular}{|c|c|c|}
\hline \multicolumn{2}{|c|}{ Dil Becerilerine Yönelik Karşılaşılan Sorunlar } & Çözüm Önerileri \\
\hline \multirow{9}{*}{ Dilbilgisi } & Cümle kuramama & Dizi izleme, şarkı dinleme \\
\hline & Zayıf dil bilgisi & Konuşmada kullanma \\
\hline & Dil bilgisini çok kötü kullanma & Çalışıyorum ama olmuyor \\
\hline & Dil bilgisini hatırlayamama & Sürekli tekrar yapma \\
\hline & Türkçenin farklı cümle yapısı ve Türkçe & Türk arkadaş edinme \\
\hline & konuşmayı zorlaştırması & \\
\hline & Dil bilgisinde zorlanma & \\
\hline & Fiili sonda kullanılması ve cümle & \\
\hline & kurmayı zorlaştırması & \\
\hline Yazma & Yazı yazmak $(\mathrm{f}=4)$ & S1k sık yazma etkinliği yapılmalı \\
\hline \multirow{4}{*}{ Kelime } & Kelime öğrenememe & Derste öğretmenin verdiklerini öğrenme \\
\hline & Türkçe kelimeleri unutma & Konuşma için öz güvenli olma \\
\hline & Uygun sözlük bulamama & Türkçe ilerledikçe TDK sözlüğünü \\
\hline & & kullanmaya başlama \\
\hline \multirow{2}{*}{ Okuma } & Hizlı okumada problem $(\mathrm{f}=2)$ & Hızlı okuma için kitap okuma \\
\hline & Uzun cümleleri anlamaması $(\mathrm{f}=2)$ & Daha çok okuma \\
\hline Dinleme & \multicolumn{2}{|l|}{ Dinlemenin vakit alıcı olması } \\
\hline \multirow{11}{*}{ Konuşma } & \multirow[t]{3}{*}{ Türklerin hızlı konuşması $(\mathrm{f}=4)$} & Daha yavaş konuşulmalı \\
\hline & & Daha fazla dinleme yapma \\
\hline & & Daha çok Türklerle konuşma \\
\hline & \multirow[t]{4}{*}{ Türkçeyi konuşmada zorlanmak (f=4) } & Daha fazla okuma \\
\hline & & Türk dizi ve filmleri izleme \\
\hline & & Okuma, dinleme ve konuşma yapma \\
\hline & & Türklerle daha çok konuşma \\
\hline & Konuşmalara karşıllık vermede & Türklerle sık sık konuşma \\
\hline & \multirow[t]{2}{*}{ Hizlı konuşamama $(\mathrm{f}=2)$} & Öğretmenlerle konuşmaya çalışma \\
\hline & & Film izleme, müzik dinleme \\
\hline & Türkçe konuşamıyorum & Türk arkadaş edinme \\
\hline
\end{tabular}


Sadece okulda Türkçe konuşma

Türklerin aksanlı konuşması $(\mathrm{f}=4)$

Sesli harflerde zorlanma $(\mathrm{f}=6)$

Telaffuz

Konuşma ve Yazı

Dili Fark1
Türk arkadaş edinilmeli

Türk arkadaş edinme

Her gün 5 saat Türkçe çalışma, müzik dinleme, Türkçe film izleme

Çok tekrar yapılmalı

Yavaş okuma

Bol bol kitap ve gazete okuma

Güzel konuşmaya çalışma

Kitap dili ve dışarıda konuşulan dilin

Okulda konuşma dersi verilmesi

Sosyal sitelerde değişik yazılması

Tablo 2 incelendiğinde, Suriyeli göçmenlerin dil becerileri konusunda Türkçenin cümle yapısının farklı olmasından dolayı sorunlar yaşadığı görülmektedir. Bunun çözümü için ise Türklerle arkadaşlıklar kurma çözüm önerisi getirilmiştir. Göçmenlerin Türkçe dil bilgisini kullanma konusunda zorlandıklarını ifade etmişlerdir. Arapçanın ve Türkçenin cümle diziliminin farklı olmasından dolayı cümle kurmakta zorlanmaları karşılaşılan bir diğer sorundur. Türkçe kelimeleri öğrenememe, unutma ve kelimeler için uygun sözlük bulamama göçmenlerin karşılaştığı sorunlar arasındadır. Arapçanın sağdan sola yazılmasından dolayı Türkçe yazı yazarken sorun yaşadıklarını ve sık sık yazma etkinliği yaparak bu sorunu çözebileceklerini ifade etmişlerdir. Kurulan uzun cümleleri anlayamama ve hızlı okuma yaşanan sorunlar arasındadır. Bunun çözümü için ise daha fazla kitap okuma önerisinde bulunmuşlardır.

Ayrıca, Suriyeli göçmenlerin Türkçeyi hızlı konuşamadıklarını, Türkçeyi konuşmanın çok zor olduğunu ve Türklerin konuşmalarının çok hızlı olduğunu ifade etmiş̧lerdir. Bu sorunu ise, Türkçe dizi ve film izleyerek, Türklerle daha fazla konuşarak ve Türk arkadaş edinerek çözüme kavuşturmaya çalıştıklarını ifade etmişlerdir. Türklerin çok farklı aksanları olduklarını bu yüzden telaffuz konusunda sıkıntı yaşadıklarını ve kitaplardaki Türkçe ile sosyal hayatta konuşulan dilin farklı olmasından kaynaklı sorunlar yaşadıklarını ifade etmişlerdir.

Suriyeli göçmenlerin Türkçe öğrenme süreçlerinde eğitim sürecine yönelik karşılaştıkları sorunlar ve çözüm önerilerinden elde edilen sonuçlar Tablo 3'te verilmiştir.

Tablo 3

Suriyeli Göçmenlerin Türkçe Öğrenme Süreçlerinde Eğitim Sürecine Yönelik Karşılaştıkları Sorunlar ve Çözüm Önerileri

\begin{tabular}{lll}
\hline Eğitim Sürecinden Kaynaklı Sorunlar & Çözüm Önerileri \\
\hline & $\begin{array}{l}\text { Kurslarda dil bilgisini öğreterek } \\
\text { başlanması } \\
\text { Bazı öğretmenlerin konuyu hızlı } \\
\text { anlatması (f=2) }\end{array}$ & $\begin{array}{l}\text { Önce dişarıda Türkçe konuşmayı öğrendim } \\
\text { sonra kursa gittim } \\
\text { Açıklamalar daha yavaş olmalı }\end{array}$ \\
& $\begin{array}{l}\text { Bazı öğretmenlerin yanlışları } \\
\text { düzeltmemesi }\end{array}$ & \\
& $\begin{array}{l}\text { Haftalık derse giren öğretmen sayısının } \\
\text { fazla olması }\end{array}$ & \\
& Ders saatlerinin kitabı bitirmek için & \\
& yeterli olmaması & \\
\hline Ders Süresi & Çok fazla bilgi verilmesi & \\
\hline İçerik & Kaynak yetersizliği & \\
\hline Kaynak & & \\
yetersizliği & &
\end{tabular}

Tablo 3 incelendiğinde, Suriyeli göçmenlerin yabancı dil olarak Türkçe öğrenme süreçlerinde, eğitim süreci kaynaklı sorunların Türkçe öğrenme süreçlerini olumsuz etkilediğinin altını çizmişlerdir. Türkçe öğretimi eğitimi veren öğretmenlerin kurslarda dil bilgisi öğreterek derse başladıklarını, konuyu hızlı anlattıklarını ve yapılan yanlışları düzeltmediklerini ifade etmişlerdir. Ayrıca derse giren öğretmen sayısının fazla olması da gösterilen sorunlardan biridir. Konuyu hızlı anlatan öğretmenlere 
çözüm önerisi olarak, öğretmenlerin konuyu anlatırken açıklamaları daha yavaş yapmaları gerektiğini dile getirmişlerdir. Türkçe öğrenmek için kaynakların yetersiz olduğu ve içerik konusunda çok fazla ayrıntı bilgi verildiği oluşan sorunlar arasındadır.

Suriyeli göçmenlerin Türkçe öğrenme süreçlerinde kendilerinden kaynaklı sorunlar ve çözüm önerilerinden elde edilen sonuçlar Tablo 4'te verilmiştir.

Tablo 4

Suriyeli Göçmenlerin Türkçe Öğrenme Süreçlerinde Kendilerinden Kaynaklı Sorunlar ve Çözüm Önerileri

\begin{tabular}{lll}
\hline Öğrencinin kendisinden kaynaklı sorunlar & Çözüm Önerileri \\
\hline $\begin{array}{l}\text { Anadili } \\
\text { kullanma }\end{array}$ & Sinıfta öğrencilerin Arapça konuşması & \\
\hline Öz-güven & Yanlış yapmaktan korkma (f=4) & Öğretmenden destek isteme \\
& Yanlış yapıldığında öğrencilerin bibrileriyle alay etmesi (f=3) & $(\mathrm{f}=3)$ \\
& Nasıl konuşulacağının bilinmemesinden dolayı utanma (f=2) & \\
\hline Kişisel & Yavaş öğrenme & $\begin{array}{l}\text { Zamana ihtiyaç duyulması } \\
\text { Evde çalı̧̧mama okulda } \\
\text { çalış̧ma }\end{array}$ \\
& Evde ne yapıllması gerektiğini bilmeme & İngilizce iletişim kurma \\
& Türkçeyi sevmeme & \\
\hline Diğer & Yanlış bir cümle kullanınca Türklerin kızması (f=2) & \\
& Kurs ücretinin burs alamayanlar için çok yüksek olması (f=2) & \\
\hline
\end{tabular}

Tablo 4 incelendiğinde, Suriyeli göçmenler, yabancı dil olarak Türkçe öğrenme süreçlerinde kendilerinden kaynaklı sorunlar da yaşadıklarını ifade etmişlerdir. Suriyeli göçmenlerin Türkçe konuşma sırasında yanlış yapmaktan korkmaları, yanlış yaptığında alay edilme korkusu ve utanma duygusunun olması özgüven eksikliğinden kaynaklanan sorunlar arasındadır. Ayrıca ortamlarda nasıl konuşacağını bilememekten kaynaklanan utanma duygusunun, öğrencilerin kendisinden kaynaklı sorunlardan birisidir. Özgüven eksikliğini gidermek için öğretmenden destek istediklerini ifade etmişlerdir. Suriyeli öğrencilerin Türkçeyi yavaş öğrendikleri ve bunun çözümü için zamana ihtiyaçları olduklarını belirtmişlerdir. Diğer yandan Türkçe konuşan Suriyeli öğrencilerin, Türkçe bir kelimeyi veya cümleyi yanlış söylediklerinde Türk arkadaşlarının kendilerine kızarak tepki verdiklerini ifade etmişlerdir. Ayrıca Suriyeli öğrencilerin sınıftaki arkadaşlarının anadilleri olan Arapçayı konuşmaları karşılaşılan bir diğer sorundur.

Araştırmanın son sorusuyla, Suriyeli göçmenlerin okulda öğrendikleri Türkçeyi okul dışında hangi durumlarda ve ne sıklıkta kullandıklarını belirlemek amaçlanmıştır. Elde edilen bulgulara göre Suriyeli göçmenlerin Türkçeyi okul dışında hangi durumlarda ve ne sıklıkla kullandıkları Tablo 5 'te verilmiştir.

Tablo 5

Suriyeli Göçmenlerin Türkçeyi Okul Dışında Kullanım Yeri ve Sıklı̆̆

\begin{tabular}{|c|c|c|c|c|}
\hline \multicolumn{2}{|c|}{ Türkçenin Kullanıldığı Durumlar } & \multirow{2}{*}{$\frac{f}{11}$} & \multirow{2}{*}{$\begin{array}{l}\% \\
42,3\end{array}$} & \multirow{2}{*}{$\begin{array}{l}\text { Kullanım Sıklı̆̆ } \\
\text { Ortalama } \\
3 \text { (Bazen) }\end{array}$} \\
\hline & Markette & & & \\
\hline & Alışveriş & 6 & 23,1 & 3 (Bazen) \\
\hline Alışveriş & AVM'lerde & 5 & 19,2 & 4 (Genellikle) \\
\hline \multirow[t]{3}{*}{ Yaparken $(\mathrm{f}=26)$} & Pazarda & 2 & 7,7 & 4 (Genellikle) \\
\hline & Çarş1 & 1 & 3,8 & 4 (Genellikle) \\
\hline & Mağazalarda & 1 & 3,8 & 3 (Bazen) \\
\hline \multirow{2}{*}{$\begin{array}{l}\text { Ulaşım Sürecinde } \\
(\mathrm{f}=24)\end{array}$} & Yolda & 15 & 62,5 & 3 (Bazen) \\
\hline & Otobüste & 9 & 37,5 & 3 (Bazen) \\
\hline \multirow{3}{*}{$\begin{array}{l}\text { Arkadaşlarla İletişim } \\
(\mathrm{f}=16)\end{array}$} & Arkadaşlarla & 7 & 43,8 & 3 (Bazen) \\
\hline & Komşularla & 3 & 18,8 & 4 (Genellikle) \\
\hline & Türkler benimle konuştuğunda & 2 & 12,5 & 4 (Genellikle) \\
\hline
\end{tabular}




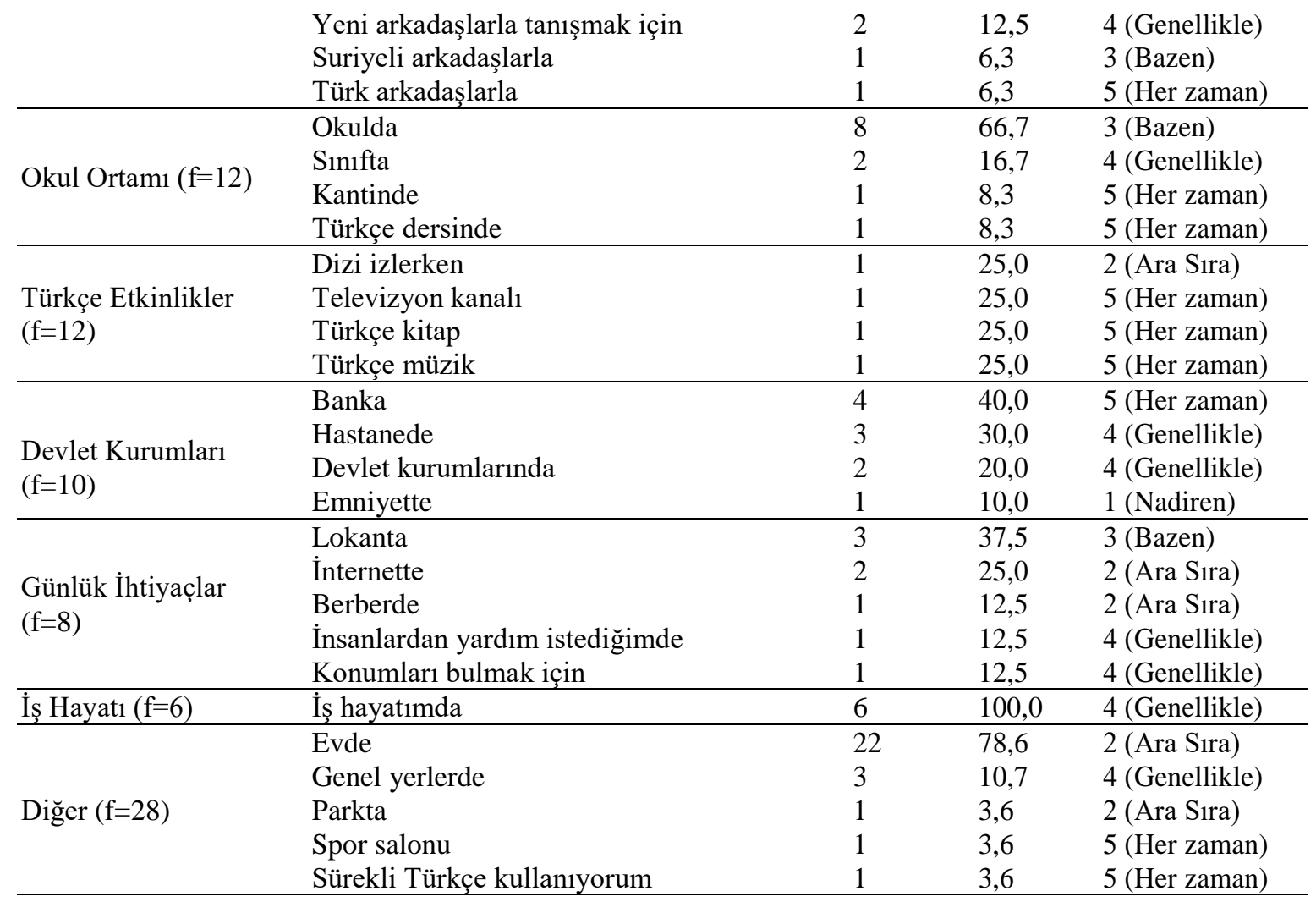

Tablo 5 incelendiğinde, göçmenlerin Türkçeyi alışveriş yaparken, ulaşım sürecinde, Devlet kurumlarında, okul ortamında, arkadaşlarla iletişim kurarken, iş hayatında, Türkçe etkinliklerde ve günlük ihtiyaçlarını karşılarken kullandıklarını ifade etmişlerdir. Göçmenlerin Türkçeyi alışveriş yaparken, ulaşım sürecinde, Devlet kurumlarında ve günlük ihtiyaçlarını karşılarken sık sık kullandıklarını; arkadaşlarla iletişim kurarken, Türkçe etkinliklerde, iş hayatı ve okul ortamında ise genellikle kullandıklarını ifade etmişlerdir.

\section{Sonuç, Tartışma ve Öneriler}

Suriyeli göçmenlerin yabancı dil olarak Türkçe öğrenme süreçlerinde, dil becerilerine yönelik karşılaştıkları sorunların başında Türkçe dil bilgisinin yani cümle yapısının farklı olması, kelimelerin öğrenilememesi, konuşmakta zorlanılması, Türkçe kelimeleri ve harfleri telaffuz etmekte zorlanmaları gelmektedir. Bölükbaş (2016), Arslan (2011), Yağmur Şahin, İşcan, Kana ve Koçer (2013), Yılmaz (2014) ile Dönmez ve Paksoy'un (2015) yaptığı araştırmalarda, Türkçe öğrenirken hem kadın hem de erkek katılımcıların en fazla konuşma becerisinde zorlandıkları sonucuna ulaşmışlardır; elde edilen bu sonuçlar çalışmadaki bulgularla örtüşmektedir. Candaş Karababa (2009), çalışmasında, Türkçe öğrenenlerin karşılaştıkları sorunları, Türkçenin ses yapısıyla, biçimbilgisi, tümce kuruluşu, anlam bilgisine ilişkin yaşanan sorunlar olarak saptamıştır. $\mathrm{Bu}$ tespitler, bu araştırmanın bulgularıyla benzerlik göstermektedir.

Araştırmada Suriyeli göçmenlerin dil becerileri konusunda Türkçenin cümle yapısının farklı olmasından dolayı sorunlar yaşadığı görülmektedir. Bunun çözümü için ise Türklerle arkadaşlıklar kurma çözüm önerisi getirilmiştir. Biçer ve Alan (2017), çalışmalarında, yabancı dil olarak Türkçe öğrenen Suriyelilerin, Türkçe kursunda Türk arkadaşlarından da yardım aldıklarını ve anlamadıkları yerleri arkadaşlarına sorduklarını saptamıştır.

Çalışmada elde edilen bulgulara göre göçmenlerin Türkçe dil bilgisini kullanma konusunda zorlandıkları ve Arapçanın ve Türkçenin cümle diziliminin farklı olmasından dolayı cümle kurmakta zorlandıklarını ifade etmişlerdir. Demirci (2015), araştırmasında, Türkçe ve Arapça arasındaki yapı ve 
menşe bakımından farklı olduğu, Türkçenin yabancı dil olarak Araplara öğretilmesinde özellikle yapı bakımından farklı dillerden olmalarının dezavantaj oluşturduğu ve edinilen dil ile hedef dil arasındaki alfabe farklılı̆̆ı, ses farklılı̆̆ı, öğrencinin moral ve motivasyonu, okumayla ilgili tavır ve tutumları, derste kullanılan materyalin fiziki özellikleri ve içerik özellikleri doğrudan etkilemektedir bulgularıyla örtüşmektedir. Bölükbaş'ın (2016) Suriyeli mültecilerin dil ihtiyaçlarının analizi adlı yaptığı çalışmada, Türkçe ve Arapçanın farklı dil ailelerine mensup olduğunu; bu nedenle bu iki dilin dil bilgisi yapısı birbirinden oldukça farklı olduğunu ve Arap öğrencilerin Türkçe öğrenirken Türkçeyi anadillerinden tamamen farklı bir yapı olarak algılamaları, olumsuz aktarımı büyük oranda engellediğinin sonucuna ulaşmıştır.

Suriyeli göçmenlerin Türkçe kelimeleri öğrenememe, unutma ve kelimeler için uygun sözlük bulamama karşılaştığı sorunlar arasındadır. Munby'e (1981) göre, konuşma becerisinde öğrenciler yabancı dilde istediği şeyi en iyi nasıl ifade edeceğini bilmemekteler ve bunu öğrenmeye ihtiyaç duymaktadırlar.

Araştırmada öğrenciler, Arapçanın sağdan sola yazılmasından dolayı Türkçe yazı yazarken sorun yaşadıklarını ve sık sık yazma etkinliği yaparak bu sorunu çözebileceklerini ifade etmişlerdir. Akkaya ve Gün (2016), Araplara Türkçe öğretiminde karşılaşllan sorunlar: Ürdün örneği isimli çalışmasında alfabe farklılığının okumada bir engel yarattığını belirlemiştir. Demirci’nin (2015) çalışmasında, iki dildeki ses farklılıkları ve alfabelerdeki birden çok sesin veya birbirine yakın seslerin bir harfle gösterilmesi gibi hususların yanı sıra metinlerin yazılış yönünün de okumayı etkilediği sonucuna ulaşmışlardır. Bu bulgular, çalışmada elde edilen bulgularla örtüşmektedir.

Suriyeli göçmenlerin Türkçeyi hızlı konuşamadıklarını, Türkçeyi konuşmanın çok zor olduğunu ve Türklerin konuşmalarının çok hızlı olduğunu ifade etmişlerdir. Türk dizi ve film izleyerek, Türklerle daha fazla konuşarak ve Türk arkadaş edinerek çözüme kavuşturacaklarını söylemişlerdir. Derman (2010), araştırmasında, Türkiye'de öğrenim görmekte olan öğrencilerin Türkiye'ye uyum süreçlerine ilişkin görüşlerine bakıldığında öğrencilerin çoğunluğunun Türk televizyonlarını dil öğrenmede ve kültürü tanımada etkin bir araç olarak nitelediklerini belirtmiş̧tir. Er, Biçer ve Bozkırlı (2012), araştırmalarında, film ve müziklerin Türkçe öğretiminde kullanılması yabancıların Türkçeye karşı tutumlarını olumlu yönde etkileyeceği sonucuna ulaşmışlardır. Bu sonuçlar araştırmanın bulgularını destekler niteliktedir.

Araştırmada elde edilen bulgulara göre, Suriyeli göçmenler, Türklerin çok farklı aksanları olduklarını bu yüzden telaffuz konusunda sıkıntı yaşadıklarını ve kitaplardaki Türkçe ile sosyal hayatta konuşulan dilin farklı olmasından kaynaklı sorunlar yaşadıklarını ifade etmişlerdir. Bir dilin yabancı dil olarak öğretilmesinde alfabe öğretimi önemli bir yere sahiptir, harfleri tanıma ve seslendirme alfabe öğretiminin ilk adımıdır, ses bilimsel farkındalık oluşturma da alfabe öğretimi için önemli bir yere sahiptir. Alfabede yer alan harflerin ses karşılıklarıyla ilgili birtakım çalışmalar yapılmalıdır. Bu da her sesin sık geçtiği kelimelerin öğrencilere telaffuz ettirilmesi şeklinde olabilir (Akkaya ve Polat, 2013). Er, Biçer ve Bozkırl1 (2012), çalışmada, Türkçe öğretilirken ders kitaplarıyla birlikte çağın teknolojisine uygun çeşitli görsel ve işitsel materyaller kullanılmalıdır. Öğrencilerde sıkça görülen telaffuz bozukluklarının birçoğu görsel ve işitsel materyallerin yeterince kullanılmamasından kaynaklanmaktadır. Türkçedeki bazı ses olayları, ünlü ve ünsüz uyumları gibi konularda da yabancıların zorlandığı görülmektedir. Seslerin telaffuzundaki zorluk hedef kitlenin diline göre değiş̧mekle birlikte $\breve{g}$, ş, ç, 1 ve ü gibi sesler yabancıların seslendirmekte zorlandığı ögelerin başında gelmektedir tespiti araştırmayla benzerlik göstermektedir.

Suriyeli öğrenciler, Türkçe öğretimi eğitimi veren öğretmenlerin kurslarda dil bilgisi öğreterek derse başladıklarını, konuyu hızlı anlattıklarını ve yapılan yanlışları düzeltmediklerini ifade etmişlerdir. Öğretmenlerin konuyu anlatırken açıklamaları daha yavaş yapmaları gerektiğini dile getirmişlerdir. Yılmaz ve Buzlukluoğlu Arslan'ın (2014) yaptığı çalışmada, öğretim elemanlarının yabancı öğrenciye yaklaşım tarzlarının Türkçeye olan ilginin, dili öğrenmede olumlu ve olumsuz olarak etkilediğini söylemiştir, bu sonuç bir bakıma bulgularımızı desteklemektedir. Erdem'in (2017) 
yaptığ 1 çalışmada, öğretmenlerin mülteci öğrencilerin ihtiyaçlarına uygun olarak öğretim stratejilerine başvurmadıklarına, kullanılan araç gereçlerin eksikliği, ders kitaplarının mülteciler için yetersiz olması sonuçlarına ulaşarak çalışmamızı desteklemiştir. Ünlü’ye (2011) göre, ders işleme sürecinde konular öğretmenler tarafından somutlaştırılmalıdır, öğretimde yalnızca öğretmen değil ders araç gereçlerinin de eksiksiz olmasının gerektiğini ileri sürmüş; dil öğretim sürecinin verimli geçebilmesi için dört temel dil becerisinin bir bütün halinde öğrencilere sunulması gerektiği sonucu araştırmadaki bulguyla örtüşmektedir. Derman'ın (2010) yabancı uyruklu öğrencilerin Türkiye Türkçesi öğreniminde karşılaştıkları sorunlar isimli çalışmasında elde ettiği sonuçlar da bulgularımızı destekler niteliktedir. Rowman (1993) ve Chen (2006), uluslararası öğrencilerle ilgili yapılan araştırmalarda, öğrencilerin ve öğretim elemanlarının kültürlerarası becerileri aktarma konusunda yetersizlikleri olduğunu; ders planlama, sınıfta dil konusunda ve öğrencilerin özel ihtiyaçları konusunda daha anlayışıı davranmaları gerektiğini saptamışlardır.

Araştırmada elde edilen bulgulara göre Suriyeli göçmenlerin, Türkçe öğrenirken kitap, dergi, film, resimler vb. gibi kaynakların yetersiz olduğu, içerik konusunda çok fazla ayrıntı bilgi verildiği ve sınıftaki arkadaşlarının anadilleri olan Arapçayı konuşmaları karşılaşılan sorunlar arasındadır. Balkar, Şahin ve Babahan (2016), araştırmalarında Suriyelilerin eğitim-öğretim süreçlerinde karşılaştıkları en büyük zorluğun Türkçe öğretimine yönelik ders kaynaklarındaki eksiklik olduğunu dile getirmişlerdir. Ders kitaplarının, özellikle Türkçe öğretimini aşamalı olarak açıklama konusunda yetersiz kaldığını düşünmektedirler. Şimşek'in (2011) yaptığı yabancılara Türkçe öğretiminde okuma metinleri ve yardımcı kitaplar isimli çalışması bulgularımızla bir bakıma örtüşmektedir. Bölükbaş’a (2016) göre, eğitim-öğretim ve materyal kaynaklı sorunların öğrencilerin Türkçe öğrenmedeki başarılarını düşürdüğünü söylemektedir. $\mathrm{Bu}$ araştırmanın tespitleri araştırmanın bulgularıyla benzerlik göstermektedir. Candaş Karababa (2009), yabancı dil olarak Türkçenin öğretimi ve karşılaşılan sorunlar isimli çalışmasında, Türkçeyi yabancı dil olarak öğrenenlerin ihtiyaçlarına ve seviyelerine uygun ders öğretim araç, gereçleri ve ders kitapları yeterli olmadığı saptamıştır.

Araştırmada elde edilen bulgulardan Suriyeli göçmenlerin Türkçe konuşma sırasında yanlış yapmaktan korkmaları, yanlış yaptığında alay edilme korkusu ve utanma duygusunun olması ve özgüven eksikliğinden kaynaklanan sorunlar olduğu sonucu ortaya çıkmıştır. Özgüven eksikliğini gidermek için öğretmenden destek istediklerini ifade etmişlerdir. Hedef kitle için motivasyon, dil öğreniminde önemli bir yeri vardır. Dil becerilerini kazanmada öğrencinin, öğrenebileceğine ve yapabileceğine olan inanc1 kişiyi tetikler (Demirci, 2015). Yabancı dil öğrenimi öğrencilerin kafasındaki acaba bu dili öğrenebilecek miyim, yanlış konuşursam arkadaşlarım bana güler mi gibi psikolojik kaygılarıyla başlar. Bu endişe ve kaygılar öğrenciyi sürekli tedirgin edebilir (Derman, 2010).

Çalışmaya katılan Suriyeli göçmenlerin, okul dışında Türkçeyi arkadaşlarıyla iletişim kurarken, okul ortamında, Türkçe etkinliklerde, iş hayatlarında genellikle kullandıklarını, alışveriş yaparken, ulaşım süreçlerinde, devlet kurumlarında ve günlük ihtiyaçları için ise sık sık kullandıklarını ifade etmişlerdir. Bölükbaş'ın (2016), Suriyeli mültecilerin dil ihtiyaçlarının analizi: İstanbul örneği isimli çalışması bulgularımızla örtüşmektedir.

\section{Öneriler}

Suriyeli göçmenler, Türkçe konuşma becerilerini geliştirmek için Türk arkadaşlarının olmadığını ve Türk arkadaş edinilmesi gerektiğini vurgulamışlardır. Bundan dolayı, Türkçe öğretim merkezlerinde «body» sistemi kurulabilir. Bu sistemde öğrencilerden Türk arkadaş ve Suriyeli göçmenlerden ikişerli gruplar oluşturulur. Öğrenciler her zaman birlikte hareket ederler.

Üniversitede Türkçe dizi, film izleme ve kitap okuma günleri gibi etkinlikler ve öğrendikleri dili kullanabilecekleri alanların ve imkânların sağlanabilmesi için çeşitli sosyal aktiviteler düzenlenebilir. 
Türkçe derslerini monotonluktan kurtarmak için sıkmayan okuma metinleri ile dört temel beceriyi geliştirmeye ilişkin etkinlikler yapılabilir.

Türkçe derslerini sorun yaşanan durumlar dikkate alınarak daha somut bir şekilde, basite indirgeyerek, yaparak yaşayarak anlatılabilir. Türkçeyi yabancı dil olarak öğrenenlerin gereksinimlerine ve düzeylerine uygun öğretim programlarının hazırlanabilir.

$\checkmark$ Yabancı dil öğretiminde görsel iletişim araçları daha etkin bir şekilde kullanılabilir.

$\checkmark$ Alfabede karıştırılan her sesin sık geçtiği kelimelerin öğrencilere telaffuz ettirilmesi ile ilgili çalışmalar yaptırılabilir. 


\section{Kaynaklar}

Akkaya, A. (2013). Suriyeli mültecilerin Türkçe algıları. Ekev Akademi Dergisi, 56(56), 179-190.

Durmuş, M.ve Okur, A. (Ed.). (2013). Yabancılara Türkçe öğretimi. Seslere dayalı alfabe eğitimi. Ankara: Grafiker Yayınları.

Aksoy, Z. (2012). Uluslararası göç ve kültürlerarası iletişim. Journal of International Social Research, $5(20)$.

Arslan, A. (2011). A new group about teaching Turkish to foreigners: refugees and refugee students. Educational Research and Review, 6(21), 1011-1017. doi:10.5897/ERR11.165

Balkar, B., Şahin, S. ve Babahan, N. I. (2016). Geçici eğitim merkezlerinde (GEM) görev yapan Suriyeli öğretmenlerin karşılaştıkları sorunlar. Eğitimde Kuram ve Uygulama, 12(6), 12901310.

Barın, E. (2008). Yabancılara Türkçenin öğretiminde motivasyonun önemi. Van Yüzüncü Yıl Üniversitesi Sosyal Bilimler Enstitüsü Dergisi, 7, 135-143.

Bekleyen, N. (Ed.). (2015). Dil öğretimi. Ankara: Pegem Yayıncılık.

Biçer, N. ve Alan, Y. (2017). Yabancı dil olarak Türkçe öğrenen Suriyelilerin ihtiyaçlarına yönelik bir eylem araştırmas1. International Online Journal of Educational Sciences, 9(3).

Bölükbaş, F. (2011). Arap öğrencilerin Türkçe yazılı anlatım becerilerinin değerlendirilmesi, 6(3), 1357-1367.

Bölükbaş, F. (2016). Suriyeli mültecilerin dil ihtiyaçlarının analizi: İstanbul örneği. Journal of International Social Research, 9(46).

Büyükikiz, K. K. ve Çangal, Ö. (2016). Suriyeli misafir öğrencilere Türkçe öğretimi projesi üzerine bir değerlendirme. Uluslararası Türkçe Edebiyat Kültür Eğitim Dergisi, 5(3), 1414-1430 doi:10.7884/teke.715

Büyüköztürk, Ş., Çakmak, E., Akgün, Ö., Karadeniz, Ş. ve Demirel, F., (2017). Bilimsel araştırma yöntemleri, (23. bask1), Ankara: Pegem Yayınc1l1k.

Candaş Karababa, Z. C. (2009). Yabancı dil olarak Türkçenin öğretimi ve karşılaşılan sorunlar, Ankara Üniversitesi Eğitim Bilimleri Fakültesi Dergisi. 42 (2). 265-277.

Chen, L. (2006). Internationalizing Canadian graduate education: East Asian international students' perspectives. Scarborough, Ontario, Canada: University of Toronto, Department of management.

Demirci, M. (2015). B1 seviyesinde Türkçe öğrenen Suriyeli öğrencilerin sesli okuma becerisiyle ilgili tespitler. 10(7), 333-358. http://dx.doi.org/10.7827/TurkishStudies.8149

Derman, S. (2010). Yabancı uyruklu öğrencilerin Türkiye Türkçesi öğreniminde karşılaştıkları sorunlar, Selçuk Üniversitesi Illahiyat Fakültesi Dergisi, 29, 227-247.

Dönmez, M.İ. ve S. Paksoy. (2015). Türkiye'de öğrenim gören Suriyeli öğrencilerin Türkçe öğrenmede karşılaştıkları sorunlar üzerine bir araştırma: Kilis 7 Aralık Üniversitesi örneği. 
International Journal of Languages' Education and Teaching UDES, 1907-1919. doi:10.18298/ijlet.366

Er, O., Biçer, N. ve Bozkırlı, K. Ç. (2012). Yabancılara Türkçe öğretiminde karşılaşılan sorunların ilgili alan yazını 1şığında değerlendirilmesi. Uluslararası Türkçe Edebiyat Kültür Eğitim (TEKE) Dergisi, 1(2).

Ekiz, D. (2009). Bilimsel araştırma yöntemleri. Ankara: Ani Yayıncılık.

Karadăg, N. (2016). Yükseköğretimde uluslararasılaşma bağlamında Türkiye'de eğitim gören Suriyeli öğrenciler üzerine bir araştırma. Electronic Turkish Studies, 11(19).

Lordoğlu, K. (2015). Türkiye’ye yönelen düzensiz göç ve işgücü piyasalarına bazı yansımalar. Çalışma ve Toplum. 44, 29-44.

Munby, J. (1981). Communicative syllabus design. Cambridge: Cambridge University Press.

Okur, A. (2013). Illk okuma ve yazma ögretimi. Türkçe ögretimi. Ankara: Pegem akademi yayınc1lık.

Özbay, M. ve Melanlığlu, A. G. D. (2008). Türkçe eğitiminde kelime hazinesinin önemi. Yüzüncü Yıl Üniversitesi Eğitim Fakültesi Dergisi, 5(1).

Özyürek, R. (2009). Türk devlet ve topluluklarından Türkiye üniversitelerine gelen Türk soylu yabanc1 uyruklu öğrencilerin Türkçe öğrenimlerinde karşılaştıkları sorunlar, Turkish Studies, 4(3), 1819-1862.

Rowan, R. (1993). The attitudes and opinions of international students studying in the college of education at the University of Minnesota. (Unpublished Master's Thesis), University of Minnesota, Minneapolis.

Şahin, C. (2001). Yurt dışı göçün bireyin psikolojik sağlığı üzerindeki etkisine ilişkin kuramsal bir inceleme. Gazi Üniversitesi Gazi Eğitim Fakültesi Dergisi, 21(2).

Şimşek, P. (2011). Yabancılara Türkçe ögretiminde okuma metinleri ve yardımcı kitaplar üzerine bir araştırma, Yayımlanmamış Yüksek Lisans Tezi, Afyon Kocatepe Üniversitesi Sosyal Bilimler Enstitüsü, Afyon.

Tunç, A. Ş. (2015). Mülteci davranış1 ve toplumsal etkileri: Türkiye'deki Suriyelilere ilişkin bir değerlendirme. Tesam Akademi Dergisi, 2(2), 29-63.

Ünlü, H. (2011). Türkiye'de ve dünyada Türkçenin yabancılara öğretiminde karşılaşılan sorunlar ve çözüm önerileri, Gazi üniversitesi Türkçe Araştırmaları Akademik Öğrenci Dergisi, 1(1), 108116.

Yayl1, D. ve Y. Bayyurt ( Ed.) (2014). Yabancllara Türkçe öğretimi. Ankara: Pegem Yayıncılık.

Yağmur Şahin, E. İşcan, A. Kana, F. ve Koçer, Ö. (2013). Yabancı dil olarak Türkçe öğrenen öğrencilerin ihtiyaç algıları: Betimsel bir durum çalışması. The Journal of Academic Social Science Studies, 6(4), 1185-1198. doi: 10.9761/JASSS996

Yılmaz, F. ve Buzlukluoğlu Arslan, S. (2014). ÇOMÜ Tömer' de Türkçe öğrenen yabanc1 öğrencilerin motivasyon kaynakları ve sorunları. International periodical for the languages, 
literature and history of Turkish or Turkic volume, 9(6), 1185-1196Y1lmaz, F. (2014). An investigation into students' Turkish language needs at Jagiellonian University in Poland. Educational Research and Reviews, 9(16), 555-561. doi:10.5897/ERR2013.1701 


\section{Extended Abstract}

The civil war that started in 2011 has influenced our country materially and morally. Millions of emigrants have migrated into our country from Syria. As a result of this immigrant, the necessity for people from different cultures to live together has aroused some problems. Education, one of the most important problems, requires a major planning. The main problem of education is the fact that Syrian people's mother-tongue is not Turkish. Therefore, teaching Turkish takes primacy. The ministry of education, universities and some non-governmental organizations have opened Turkish courses for Syrian people. Teaching Turkish at universities has been carried out by Teaching Turkish Centers. This study aims to find out the problems that these emigrants have faced while learning Turkish, the solutions that have been suggested for these problems, and how often and in which conditions they use Turkish. This qualitative research has been conducted with 33 Syrian emigrants who took a B-2 level Turkish course at a state university in 2016-2017 academic year, through semistructured interview form. To analyze the data, content analysis method was used. The analysis reveals that the Syrian emigrants facing such problems as different Turkish sentence structure, lack of feedback and lack of self-confidence in their Turkish courses use Turkish in their daily life for dailyneeds.

Key words: Teaching Turkish to foreigners, emigrants, problems

\section{Introduction}

The civil war that started in 2011 has influenced our country materially and morally. Millions of emigrants have migrated into our country from Syria. As a result of this migration, the necessity for people from different cultures to live together has aroused some problems. Education, one of the most important problems, requires a major planning. The main problem of education is the fact that Syrian people's mother-tongue is not Turkish. Therefore, teaching Turkish takes primacy. The ministry of education, universities and some non-governmental organizations have opened Turkish courses for Syrian citizens. Teaching Turkish at universities has been carried out by Teaching Turkish Centers. Of course, In normal conditions, the emigrants who want to learn Turkish as a foreign language willingly without any obligations and pressures will have different problems than those who have to learn the language just because they have to survive and adopt to other societies beyond their will power. These problems are readiness, willingness to learn, and the socioeconomic, cultural and psychological differences. It is difficult to teach Turkish to those who have many negative effects. In order for the process to run smoothly, first of all, it is important that the community to have language education be analyzed and what to consider to ease this process be identified correctly. So, that the language requirements of the Syrian emigrants should be determined and that the content and the environment of courses to be given should be prepared accordingly bears a big necessity (Bölükbaş, 2016: 21).

As a result, if the language requirements of the Syrian emigrants who face many problems while learning Turkish as a foreign language and for this reason, the social adaptation is delayed and the program and the learning environments are prepared in line with these requirements, the Syrian refugees' adaptation to the life in Turkey and their acculturation process can gain speed (Büyükikiz ve Çangal, 2016: 1417).

The data obtained in this very study, the aim of which is to identify the problems that Syrian immigrants have faced while learning Turkish as a foreign language, is thought to help the formation of the Turkish as a foreign language teaching programs. Besides, this study bears importance for the public institutions related to educational, socio-cultural and economical situations to determine necessary policies.

\section{Aim of the Study}

This study aims to find out the problems that Syrian emigrants have faced while learning Turkish, the solutions that have been suggested for these problems, and how often and in which conditions they use Turkish. 


\section{Research Questions}

1. What kind of problem do the Syrian emigrants face while learning Turkish?

2. What solutions do the Syrian emigrants suggest for the problems they face?

3. In which situations and how often do the Syrian emigrants use Turkish except the school they are learning Turkish?

\section{Method}

Qualitative research was used in this research. 33 Syrian emigrants (13 women; 20 male) attending a B-2 level Turkish course at a state university in 2016-2017 academic year participated in the study voluntarily. The data were collected through semi-structured interview form. To analyze the data, content analysis method was used and the reliability of the content analysis was found to be 95 .

\section{Findings}

The problems the Syrian i emigrants face while learning Turkish were seen to group under three themes: language skills, instructional process and student. It was found that the Syrian emigrants have difficulties in all language skills in Turkish. They stated that they cannot use Turkish grammar because Arabic and Turkish have different sentence structures and alphabets. Another problem they face about language skills is that they cannot learn Turkish words in that they have no appropriate dictionary and they forget the words easily. Since Arabic is written from right to left, the Syrian emigrants find it difficult to write in Turkish which is written from left to right. Besides, they can not understand long sentences and the reading texts, which are read fast in class. To overcome these problems, they underline the fact that they should have Turkish friends and read more books, watch Turkish movies and TV series, use Turkish more often.

The problems related to instructional process were found to affect the Syrian emigrants' Turkish language learning process negatively. They stated that the teachers started the lessons with grammatical rules, were fast and did not correct the errors they made. Furthermore, orher problems the Syrian emigrants underlined are that the number of the teachers for a group is too many, that there are not enough materials to learn Turkish and that the teachers focus on too much details. For the solutions to these problems, they highlighted that the teachers should be slow and not give too much details when instructing.

Syrian emigrants shed light on the problems they cause during their Turkish learning process. They stated that since they lack self-confidence, they are afraid of making mistakes and being ridiculed and they are ashamed. In order to overcome this problem, they ask for support from their teachers and they need time to learn the language. Another problem is that they speak their mother tongue in class among their classmates because all of them are Syrians.

Lastly, the Syrian emigrants stated that they use Turkish during shopping, transportation and official business, communicating with Turkish friends.

\section{Conclusion}

Syrian emigrants stated that in order to develop their Turkish speaking skills, they don't have many Turkish friends and they should meet more Turks and become friends. Because of this, In Turkish language teaching centers, a "body" system can be initiated. In this system, a person speaking Turkish well and a Syrian immigrant become pairs and spend their time together. Such environments as Turkish movie day or reading day can be created for these students to use the target language effectively. Teachers can simplify the topics and instruct them in a way that they actively participate in the activities. Besides, a curriculum can be prepared considering the needs and levels of the learners learning Turkish as a foreign language. Audio visual materials should be used extensively in Turkish language teaching. To overcome the pronunciation problems, more pronunciation activities on the sounds often confused should be provided. 